\title{
USE OF LACCASE-PRODUCING MICROORGANISMS IN MEMBRANE SYSTEMS FOR POLLUTING AGENTS REMOVAL: CONSIDERATION AND PERSPECTIVES
}

\author{
Liliana Serna C. ${ }^{1 *}$, and Fernando L. Cuesta A.
}

\begin{abstract}
A B S T R A C T
Contamination is defined as the presence of pollution agents in an ecosystem reaching an abnormal concentration level and causing adverse effects. Due to the important environmental problems that these cause in the food chain, diverse methods have been formulated to minimize those effects; among these enzymatic methods associated to microorganisms or other biological agents are used, and systems that allow to metabolize pollutants in an effective and practical way. The combined use of these systems appears to be the most appropriated option to eliminate pollution agents at a reasonable energy cost which allows their use in the industry. The present review identifies the adequate process conditions for technological implementation of biofilm-type membrane systems where laccase-producing microorganisms are used as decontamination agents.
\end{abstract}

Key words: laccase, biofilm, membrane system, halogen compound.

\section{INTRODUCTION}

Contamination is defined as the introduction of some substances or energy forms into an ecosystem that on reaching an abnormal concentration level cause adverse effects. Due to the interaction between the aquatic, earth and atmospheric environments, the circulation of contamination agents has important consequences; the contamination components and their action in the ecosystem which have been comprehensively studied are listed in Table 1.

In the atmosphere, the primary pollution agents are particulate materials (PM), nitrogen oxides (NOx) sulphur dioxide $\left(\mathrm{SO}_{2}\right)$, sulphite reducing gases (TRS), carbon dioxide $\left(\mathrm{CO}_{2}\right)$ and carbon monoxide $(\mathrm{CO})$. All of these are involved in the destruction of the ozone layer when they react with the components of the air. The damage to the protective layer against ultraviolet radiation (UV) is produced by the emission of gases that contain chlorine, forming the chlorofluorocarbons (CFC) which release chlorine atoms $(\mathrm{Cl})$ when they reach the stratosphere, being each of these atoms responsible for the breakup of many ozone molecules $\left(\mathrm{O}_{3}\right)$ transforming them into oxygen and chlorine monoxides; chlorine monoxides are removed from the atmosphere during precipitations.

Chlorine reacts with water, forming hydrochloric and hypochloric acids, among others. Ionization of the hydrochloric and hypochloric acids reduces water $\mathrm{pH}$; in the long-term this affects the physiological functions of water organisms. The action of chlorine acids modifies the activity and the quaternary structure of metallothionein (MT). This protein is involved in the transference of metallic ions in water organisms and in the homeostasis of metals at the physiological level; therefore the presence of chlorine acids in estuaries causes metabolic disturbances and increases the respiration rate (Mandel, 2007).

Due to its gaseous nature, $\mathrm{Cl}$ is rarely found in its pure form in soil. If it is released into the soil it reacts with water, forming hypochloric acid and hydrochloric acid; these can react with elements in the soil, forming enzyme inhibition compounds which act especially at the extracellular level. Extra-cellular enzymes act as a physical or chemical limit to mineral and organic surfaces. For example, acid phosphatase is one of the many functional phosphatases in the soil and the main agent responsible for the mineralization of organic phosphate compounds in acid soils. An inhibition of the enzyme complex alters the cellular homeostasis of the agents related with the system (Huang, 2003).

\footnotetext{
${ }^{1}$ Universidad Nacional de Colombia, Facultad de Ingeniería, AA237, Palmira, Colombia.

E-mail: 1sernac@palmira.unal.edu.co; flcuestaa@palmira.unal.edu.co *Corresponding author.

Received: 20 September 2007. Accepted: 4 February 2008.
} 
Table 1. Main chemical pollutant agents and their action in the ecosystem.

\begin{tabular}{lll}
\hline Chemical compound & \multicolumn{1}{c}{ Action in the ecosystem } & \multicolumn{1}{c}{ Reference } \\
\hline $\begin{array}{l}\text { Chlorofluorocarbons } \\
(\mathrm{CFCs})\end{array}$ & $\begin{array}{l}\text { Break ozone molecules }\left(\mathrm{O}_{3}\right) \text { into oxygen and chlorine } \\
\text { monoxide. }\end{array}$ & Darling and Gooddy, 2007. \\
\hline $\begin{array}{l}\text { Hydrochlorofluorocarbon } \\
(\mathrm{HCFCs})\end{array}$ & $\begin{array}{l}\text { Involved in the transformation of oxygen into carbon } \\
\text { monoxide. }\end{array}$ & $\begin{array}{l}\text { McCulloch } \text { et al., 2006; } \\
\text { Derwent } \text { et al., 2007. }\end{array}$ \\
\hline Nitrous oxide $\left(\mathrm{NO}_{\mathrm{x}}\right)$ & $\begin{array}{l}\text { Generates acid rain, reacts with water in the atmosphere forming } \\
\text { sulfuric and nitric acids. }\end{array}$ & Fang and Mu, 2007. \\
\hline $\begin{array}{l}\text { Polycyclic aromatic } \\
\text { hydrocarbons (PAHs) }\end{array}$ & $\begin{array}{l}\text { Formed as a consequence of incomplete combustion of organic } \\
\text { matter, they are mutagenic and carcinogenic. The chlorine } \\
\text { component enters into the cell membrane structure modifying }\end{array}$ & and Lee, 2004; Whiteley \\
& intra and extracellular regulation functions. & \\
\hline Chlorophenols & $\begin{array}{l}\text { Persistent organic compounds, containing one or more chlorine } \\
\text { atoms in their molecules. Carcinogenic, they act on the immune, et al., 2007; Sahinkaya and } \\
\text { reproductive and nervous systems. At cell level, they cause } \\
\text { metabolic disorders and damages in the enzyme system. }\end{array}$ & Dilek, 2007. \\
\hline
\end{tabular}

Whether the polluting agents are in the air, water or soil, the problem must be faced in a global manner, since it affects several ecosystems. At the industrial level, the handling of effluents relies on stabilization zones, where the action of microorganisms leads to an oxidation of the pollution component. However, whether the process is anaerobic or aerobic, the system requires a large amount of space and involves important energy and operational costs. Concerning gaseous emissions, the technological alternatives are the destruction of the pollutant, employing chemical and catalytic methods, and the recuperation of contaminated air, which is no more than a series of filtering operations to classify the PM. Besides, there are studies which support the action of certain plants and their associated microorganisms, which exert a mitigating action in the control of atmospheric emissions, to degrade, contain or stabilize environmental contaminants (Montgomery, 2004; Ramos, 2005); this is possible due to the action of the microbiologic-enzymatic systems which involve nitroreductase, dehalogenase, peroxidase, nitrilase and mostly laccase. However, the bioremediation process requires a long time and it is not convenient to couple it to productive processes.

Due to the difficulties mentioned, the idea has arisen to employ enzymes associated to biofilm-type membrane systems, regardless of the polluting agent type of discharge. These systems allow for the transformation of contaminants in an effective manner, at a reasonable energy cost and are suitable for their use in industry. Consequently, the purpose of this article is to review enzymatic methodologies involving laccase-producing microorganisms coupled to an artificial membrane medium as decontamination agent.

\section{Membrane systems associated to laccase-producing microorganisms}

Laccase (EC 1.10.3.2) is a polyphenol oxidase which acts on $\rho$-diphenols; some of these contain halogen elements in their structure (Xu, 1996). Its catalytic site is characterized by four copper $(\mathrm{Cu})$ atoms, which couple to four electrons of the reduction of dioxygen to water in the oxidation of the respective substrate (Solomon and Sundaram, 1996).

There are numerous laccase-producing microorganisms; however, advanced studies in the use of microorganisms attached as laccase producer are focused on a prokaryote belonging to the Bacillaceae family, and fungal organisms associated to organic material rotting processes (Table 2 ), due to their adaptation to variable media and to their capacity of forming a biofilm-type matrix. Cunninghamella elegans, Aspergillus niger, Penicillium spp., Phanerochaete chrysosporium, Pleurotus ostreatus, Trametes versicolor and Bjerkandera $\mathrm{sp}$. have shown adaptation to media with a considerable concentration of polycyclic aromatic hydrocarbons (PAHs); they have been able to develop and present a significant potential to metabolize the pollution agent (Cerniglia and Sutherland, 2006).

Membrane systems are structural polymers in charge of providing optimum conditions for the development of the attached microorganisms. Depending on the characteristics of these systems, the action of their enzyme complexes and the removal of the polluting agents in different kinds of effluents are ensured. They are employed as support and development structures, for the microorganism and enzyme production medium 
Table 2. Laccase-producing microorganisms.

\begin{tabular}{|c|c|c|}
\hline Microorganism & Type & Reference \\
\hline Trametes pubescens & White rot fungus & Osma et al., 2007 \\
\hline Pleurotus ostreatus & Basidiomycete & Prasad et al.,2005 \\
\hline Cerrena unicolor & White rot fungus & Jarosz-Wilkolazka et al., 2006 \\
\hline Abortiporus biennis & White rot fungus & Jarosz-Wilkolazka et al., 2006 \\
\hline Bjerkandera spp. & White rot fungus & Novotny et al., 2000; Cerniglia and Sutherland, 2006 \\
\hline Coriolopsis spp. & White rot fungus & Novotny et al., 2000; Cerniglia and Sutherland, 2006 \\
\hline Irpex spp. & White rot fungus & Novotny et al., 2000; Cerniglia and Sutherland, 2006 \\
\hline Phanerochaete spp. & White rot fungus & Novotny et al., 2000; Cerniglia and Sutherland, 2006 \\
\hline Pleurotus spp. & White rot fungus & Novotny et al., 2000; Cerniglia and Sutherland, 2006 \\
\hline Trametes versicolor & White rot fungus & Cerniglia and Sutherland, 2006; Akzu et al., 2007 \\
\hline Neurospora crassa & Ascomycete & Luke and Burton, 2001 \\
\hline Hirschioporus laricinus & White rot fungus & Banat et al., 1996 \\
\hline Inonotus hispidus & White rot fungus & Banat et al., 1996, Kirby, 1999 \\
\hline Phlebia tremellosa & White rot fungus & Banat et al., 1996, Kirby, 1999 \\
\hline Phanerochaete chrysosporium & White rot fungus & Banat et al., 1996, Kirby, 1999; Gnanamani et al., 2006 \\
\hline Funalia trogii & White rot fungus & Ünyayar et al., 2005 \\
\hline Coriolus versicolor & White rot fungus & Kapdan et al., 2000 \\
\hline Cunninghamella polymorpha & White rot fungus & Sugimori et al., 1999 \\
\hline Geotrichum candidum & White rot fungus & Lee et al., 2000 \\
\hline Rhizopus arrhizus & White rot fungus & Aksu and Tezer, 2000 \\
\hline Fusarium solani & White rot fungus & Verdin, 2004 \\
\hline Dichomitus squalens & White rot fungus & Kunla et al., 2007 \\
\hline Trichophyton rubrum & White rot fungus & Jung et al., 2002 \\
\hline Trametes hirsuta & White rot fungus & Rosales et al., 2007 \\
\hline $\begin{array}{l}\text { Chalara (syn. Thielaviopsis) } \\
\text { paradoxa }\end{array}$ & Hyphomycete & Robles et al., 2002 \\
\hline Bacillus spp. & Bacteria & Dalfard et al., 2006 \\
\hline
\end{tabular}

and act as selective permeable barriers to the movement of structures or chemical compounds between two phases or conditions. Their geometric configuration depends on the endogenous characteristics of the microorganism (Wang and Wang, 2006); this field is open to far reaching research.

Due to the artificial nature of the membrane, the symbiotic development between the laccase-producing microorganism and the membrane matrix is the subject of this study. On the structural level, the most important characteristics of membrane systems are the morphology, size and density of membrane pores, statistical distribution of pore size, flow turbulence and volume occupied by the pores. These concepts are discussed in Table 3. As regards the functional characterization of the membrane system, what is studied is the permeability of the membrane, retention coefficients, separation factors, the adsorption characteristics, effective diffusion coefficients and various tests of chemical, mechanical and physical compatibility.

Microbial growth conditions in membrane systems The growth of enzyme-producing microbial cells in membrane systems can be carried out in aerobic and anaerobic conditions.

The capacity of enzymes to act in metabolic activities involving aerobic conditions is affected by a diversity of factors such as the nutritional composition required by the attached microorganism, the medium $\mathrm{pH}$, the temperature profile, the membrane porosity and particles the retention (Dalfard et al., 2006; Gnanamani et al., 2006; Aksu et al., 2007). The dissolved oxygen level becomes a parameter of the process which determines membrane filterability. At high levels of dissolved 
Table 3. The most important structural characteristics of membrane systems associated to laccase-producing microorganisms.

\begin{tabular}{lll}
\hline Structural characteristic & \multicolumn{1}{c}{ Justification } & \multicolumn{1}{c}{ Reference } \\
\hline $\begin{array}{l}\text { Morphology and average size of the } \\
\text { pores }\end{array}$ & $\begin{array}{l}\text { Generally expressed as a form factor and a } \\
\text { radius or diameter value of equivalent pore }\end{array}$ & $\begin{array}{l}\text { Wang and Wang, 2006; } \\
\text { Vladisavljević } \text { et al., 2006 }\end{array}$ \\
\hline Surface density of the pores & $\begin{array}{l}\text { Distribution of the number of pores in area unit } \\
\text { of a membrane system }\end{array}$ & Tran et al., 2006 \\
\hline Volume of porosity & $\begin{array}{l}\text { Fraction of the total volume of the membrane } \\
\text { which is occupied by pores or holes }\end{array}$ & $\begin{array}{l}\text { Khayet, 2003; Wang and } \\
\text { Wang, 2006 }\end{array}$ \\
\hline Tortuosity & $\begin{array}{l}\text { Pores are not generally cylindrical, so the area } \\
\text { occupied at the surface does not correspond to } \\
\text { the volume occupied within the membrane }\end{array}$ & $\begin{array}{l}\text { Li and Wang, 2006; Sun } \text { et } \\
\text { al., 2006 }\end{array}$ \\
\hline Statistical distribution of pore sizes & $\begin{array}{l}\text { There is no uniformity in the physical } \\
\text { characteristics of the pores and their distribution } \\
\text { within the membrane system }\end{array}$ & $\begin{array}{l}\text { Khayet, 2003; Wang and } \\
\text { Wang, 2006 }\end{array}$ \\
\hline
\end{tabular}

oxygen, the resistance in the membrane increases, this reflects in the porosity of the membrane and its capacity to retain the particle material of the effluent (Jin et al., 2006).

There are few studies involving the development of biological organisms producing enzymes for the removal of polluting compounds in aerobic conditions. In the removal of polluting agents by laccase, the reactive oxidation of the polluting agent is less effective in aerobic conditions due to the characteristics of production of the enzyme.

The mechanisms involved in anaerobic processes are reductive dechlorination, where a halogen group is replaced by a hydrogen group, involving the transfer of two electrons, and dehalorespiration, a mechanism where a chlorinated hydrocarbon is employed as electron acceptor to aid microbial growth.

Both aerobic and anaerobic metabolic pathways, are efficient for the removal of polluting compounds; however, there are direct and indirect advantages that point to a process without an external electron acceptor. When oxygen appears as the sole electron acceptor, dissolved oxygen is a control parameter of the process (Jin et al., 2006); the disposition of the stabilization zones is more demanding in aerobic processes, either due to physical management or to raw material requirements (Savant et al., 2006) and the aerobic processes involve the volatilization of organic compounds, this implies another phase of the process (Kosaric and Blaszczyk, 1991). On the contrary, subproducts of anaerobic conditions, with high caloric content, can be re-circulated to other phases of the productive process (Rajeswari et al., 2000).

\section{Types of reactors associated to a membrane matrix and operating modes}

The reactors involving the use of a permeable membrane of the biofilm type are of the packed-bed (Canovas-Diaz and Howell, 1988), which in addition employ natural or synthetic materials as support for the membrane (Table 4). The process begins with a flow of water followed by a counter-current flow of air. The microorganisms attached to the membrane matrix develop until they reach a stabilization phase, where an efficient removal of the noxious agents takes place. Some drawbacks may arise in the operation of this type of reactor, such as a low degradation rate and the heterogeneity of the membrane during the process. This brings about an accumulation of polluting agents in high concentrations in the membrane structure, and this is noxious to the attached microorganisms. The affinity of the enzyme for the substrate is also relevant in the removal of polluting agents by means of packed bed reactors; laccase has a high affinity to phenolic and p-diphenolic compounds (Robles et al., 2002); however, enzyme inhibitors modify enzymatic activity, resulting in an inadequate action against polluting agents; particularly, the presence of compounds containing $\mathrm{Fe}_{2}{ }^{+}, \mathrm{Ag}_{2}{ }^{+}$, and $\mathrm{Cu}_{2}{ }^{+}$affects the formation of the enzyme substrate complex, causing a low degradation rate (Xu, 1996; Robles et al., 2002).

A configuration which considerably improves mass transfer is to use membranes as independent barriers; these act in a counter-current of air and water (Figure 1). The geometric configuration of the membrane must be defined, as it must be fitted to the characteristics of the microorganism. The ideal strategy is to use tubular structures, because the contact surface is greater than in 
Table 4. Support materials used in reactors associated with membrane matrix.

\begin{tabular}{ll}
\hline Natural materials & Reference \\
\hline Soil materials & Smet et al., 1996 \\
Compost & Cho et al., 2000 \\
Moss soil materials & Yang and Allen, 1994 \\
Wood shavings & Cho et al., 2000 \\
Rock's zones with low levels of silica & Nukunya et al., 2005 \\
& \\
Synthetic materials & \\
Ceramic support & Gabriel and Deshusses, 2003 \\
Polyethylene filter & Sorial et al., 1998 \\
Polyurethane filter & Koe et al., 2001 \\
Foam & Kinney et al., 1996 \\
Granular activated carbon & Ho et al., 2007 \\
Extruded diatomeous soil pellets & Kim et al., 2005; Kim and Sorial, 2007 \\
\hline
\end{tabular}

a spherical configuration. As the contact surface between the membrane system and the polluting agent increases, the mass transfer indexes improve considerably due to the extracellular secretion of laccase (Luke and Burton, 2001). The configurations for anaerobic processes are similar. The only difference is the absence of air flow (Rajeswari et al., 2000).

In the analysis of mass transference for any configuration of reactor associated to membrane structures, it must be considered that: (1) the transfer of flows in aqueous or liquid phase must be mainly diffusive, since this allows partial control of the development conditions of the attached microorganism. At the intra-particle level, the nature of the substrate is mostly insoluble but microorganisms use the soluble phase of the substrate for their development. However, this mechanism must be evaluated because this process takes time; (2) the resulting metabolites must be removed quickly and efficiently, the use of forced flows appears as the best option; (3) the porosity of the membrane is an ambiguous factor, on one hand it has a negative influence on the metabolic processes inside the membrane structure (Raghavarao et al., 2003); however a degree of membrane porosity facilitates diffusion processes (Miller and Grant, 2005; Jin et al., 2006); (4) wear of the membrane lowers the efficiency of the process.

Likewise, the interaction between flow, membrane system and catalytic reaction has energetic implications which result in a global heat transference in the process, as heat loss or gain. However, the action of the attached microorganisms is sensitive to this phenomenon so it must be taken into account that: (1) the incoming and outgoing flows from the bioreactor module are the consequence of perceptible energetic changes and of the concentration of products such as $\mathrm{O}_{2}, \mathrm{CO}_{2}$, and water; (2) natural convection or diffusion mechanisms must be employed for the control of non-forced flows of gaseous phase components; (3) special care must be given to the interaction between the material of the bioreactor and the currents flowing around it. It is recommended to use convective methods for the cooling of those flows.

The configuration of reactors on pilot and laboratory scales are mostly continuous sequences of reactors, counter-current reactors, anaerobic contact filters and membrane-granular activated carbon matrix diphase reactors (Sahinkaya and Dilek, 2007).

The contaminants removal level does not depend only in the control of the effluent; an adequate characterization of the microorganisms to be employed must be made and most particularly, of their enzyme production rate; this was demonstrated by Choi et al. (2007), who found that, in spite of having effected a good control of the effluents, the removal levels of mono, di and trichlorophenols were not adequate due to the toxicity of the compound for the microorganisms and an inadequate enzyme identification. Sahinkaya and Dilek (2007) determined that the acceptable chlorophenol removal levels are of $53 \mathrm{mg} \mathrm{L}^{-1}$ for monophenols and $25 \mathrm{mg} \mathrm{L}^{-1}$ for dicholorophenols. 


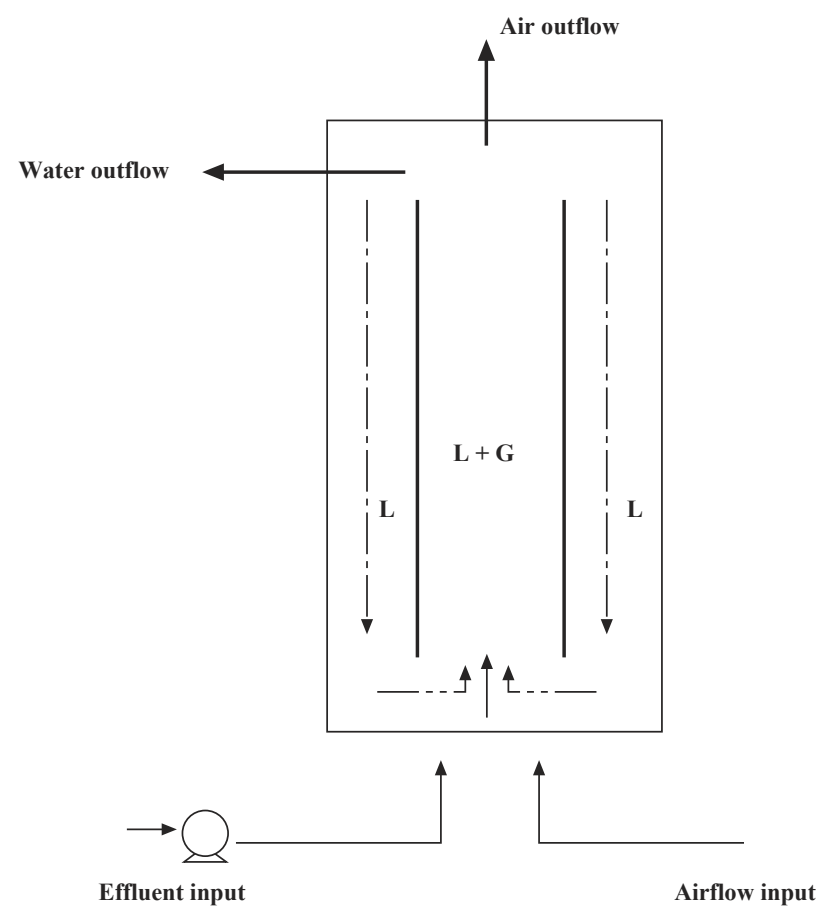

Figure 1. Reactor with immobilized membrane. L: liquid, G: gas.

Source: Rajeswari et al., 2000.

The configuration of the reactor and the support material of the membrane are also key factors of the membrane systems. For example, Alvarez (2006) using pumice stone as membrane support in a fluidized bed reactor operated the system during 300 days. This is double the time than when using conventional methodologies applied in the laboratory, which reach an acceptable operation time of 40 to 120 days.

An alternative in the research of chlorinated effluents handling is the use of solar radiation and photo catalysis, as an adjunct treatment to the membrane systems with laccase-producing microorganisms (Malato, 2003; Pedroza, 2007); after the biological action of laccase, the photo catalytic treatment mineralizes the chlorinated compound. This alternative is a promising study field, due to the increase in the production of photocells, a component of high economic value.

Aerobic and anaerobic membrane systems are also combined for the removal of polluting agents in water (Tartakovsky, 2005). The experimental method evaluates control of trichloroethylene (TCE), making use of the measured synergic action of methanogenic archaea in aerobic and anaerobic phases. Although the parameters of reference mentioned at the laboratory level are TCE removal levels and mass transference, the characteristics of the attached microorganisms are left in secondary importance.

In the processes of volatile compounds removal (VCR), the control options are centered in three technological solutions involving the use of microorganisms and the production of enzyme complexes. These are the biocleaner, bioregulating filter and biofilter (Garner and Barton, 2002). The process is based on aerobic metabolism, demanding a high humidity content to improve the temperature profile of the process and the transfer of oxygen is fundamental.

The biocleaning system includes airflow recirculation through two modules: a conventional filter to standardize the particle size and a membrane module where the oxidation of the volatile organic compounds takes place (Figure 2). The membrane system has a hydrophobic phase, which regulates the contact of the microorganism with the air flow (Freitas dos Santos et al., 1997).

The biofilter is a long duct, with nutrients for the development of microorganisms and with support materials backing the process in the transference of air flows (Nukunya et al., 2005; Bhat et al., 2006). There are 


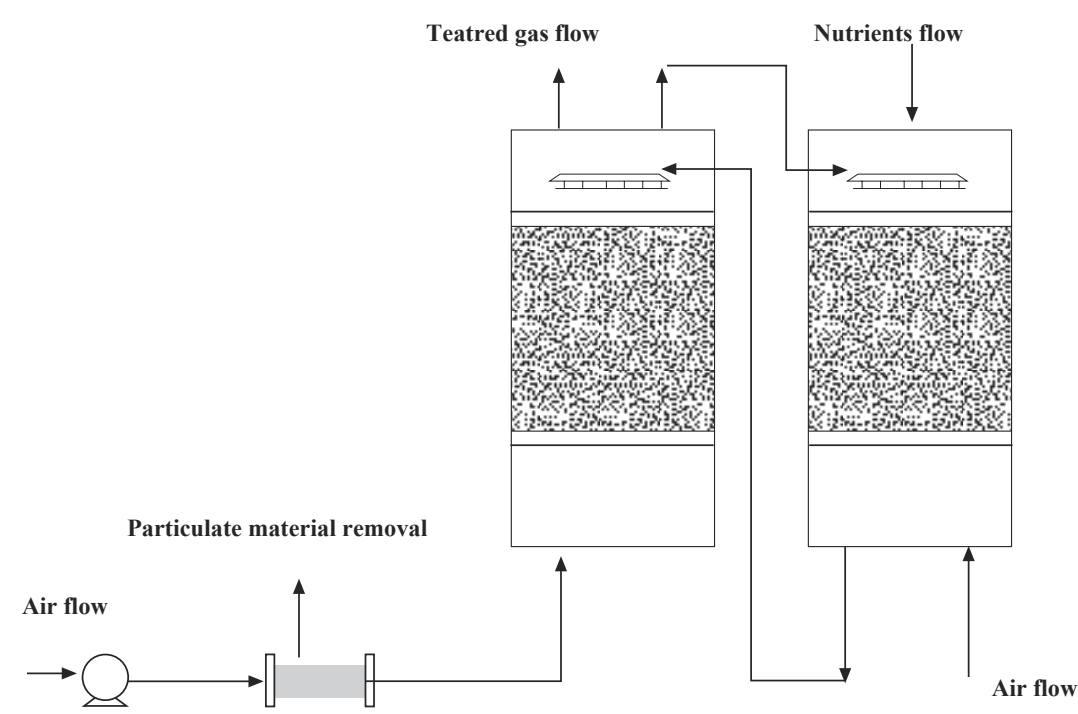

Figure 2. Bioscrubber system with flow recirculation in the modules of conventional filter and reactor.

Source: Adapted from Freitas dos Santos et al. (1997).

two phases of preparation of the flow before the contact with the air and the membrane system: a conventional filter associated with activated carbon to reduce the concentration of pollution agents and a humidification module to increase the humidity content and cool the air current. Two operations are identified in the membrane module: (1) the transference of polluting agents from the gaseous to the aqueous phase, which depends mostly on the characteristics of the substrate in the membrane structure, flow condition of the aqueous phase, nature of the transference of agents, possible recirculation of the same in the flows converging in the process and diffusion values of the pollution agents (Jin-Ying et al., 2005); (2) the oxidation of the contamination agents by the attached microorganisms.

The biodosifier filter operates on the same parameters as the previous process. However, it differs in the humidification phase of the airflow. The membrane system that comes into contact with the airflow has an adequate humidity content to favor the contact and action of the attached microorganism. Humidification takes place by counter-current trickling (Soccol et al., 2003). The system is similar to the operation of a gas absorption tower (Figure 3). A drawback of the biodosifiers is the control of the convective and conductive heat transference through the membrane system, if this is not adequate, the development of the microorganisms would be affected. This aspect is not often reported in scientific literature.

\section{Fields of exploration for the application of membrane} systems in the removal of pollution agents

The literature examines several fundamental aspects for the investigation of membrane systems, these are: the use of transgenic lines, strategies to increase enzyme production yields, modeling of enzyme production kinetics and mass transfers, and the assessment of different substrates.

In order to model the kinetic processing of a pollution agent, a wide knowledge of the following aspects is required: (1) diffusion coefficients of the pollution agent in the aqueous, air and atmospheric environments; (2) conditions associated to the environment such as temperature and $\mathrm{pH}$, and (3) concentration of the pollution agent.

On the other hand, filtering always appears as a previous step to the membrane system and the characteristics of the filter to remove pollution agents is another aspect susceptible of study. To use soil materials favorable to the development of microorganisms ensures the catalytic action on the noxious compound and so the toxicity level is drastically reduced, assuring a longer operational time in the bioreactor phase. An alternative is to use soil substrates of mineral type (Gadd, 2007) which allow the development of microorganisms, mostly fungi, which high enzyme production levels. 


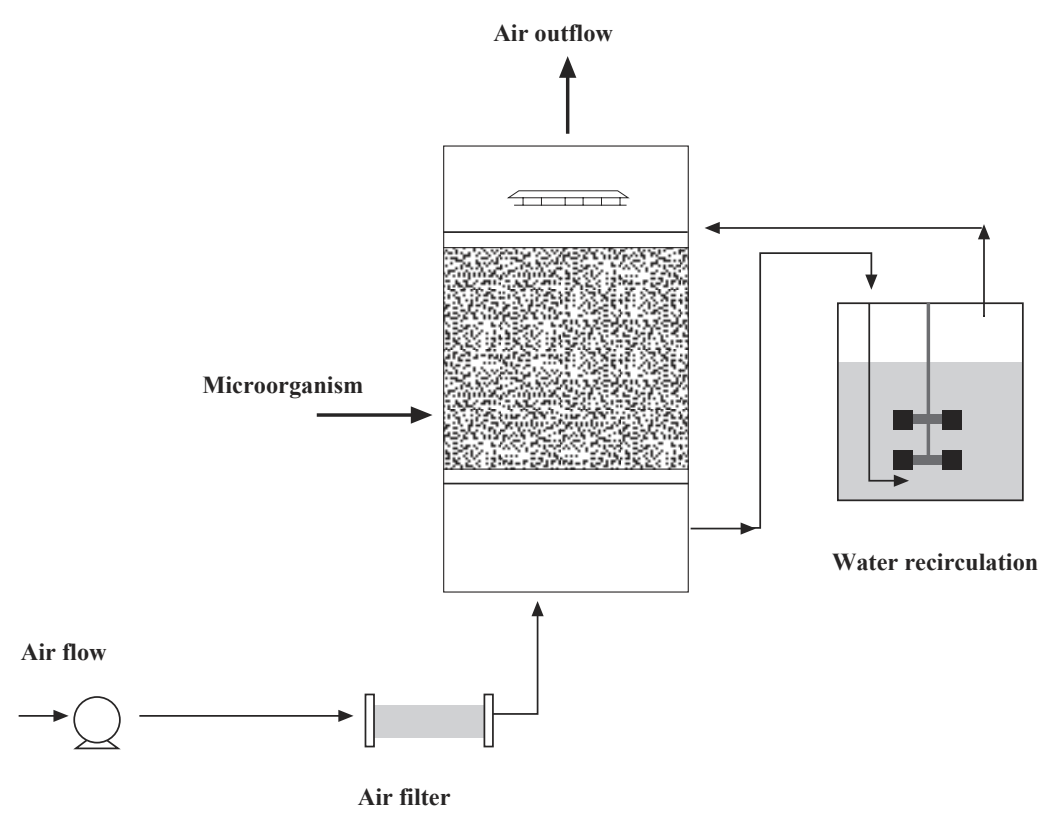

Figure 3. Biodispenser with a recycling of water for humidification processes Source: Adapted from Soccol et al., 2003.

\section{CONCLUSIONS}

To employ membrane systems with laccase-producing microorganisms and obtain their development as they come into contact with liquid or gaseous flows containing compounds of a high degree of toxicity, especially of halogen elements, has turned into a promissory technology with a wide range of application; however, the problems to put the technological tools into operation on an industrial scale are still considerable. Membranes can vary significantly in their structure and constitution and their functional behavior is therefore different; any change can modify their structure and consequently reduce the efficiency of contaminants removal. For this reason the membrane materials, their behavior in the bioreactor and their affinity with the attached microorganism, are fields open to further research.

\section{RESUMEN}

Empleo de microorganismos productores de laccasa en sistemas membranarios para remoción de agentes de polución: consideraciones y perspectivas. Liliana Serna C. ${ }^{1 *}$, y Fernando L. Cuesta A. ${ }^{1}$ La contaminación se define como la presencia en un ecosistema de agentes de polución que alcanzan un nivel de concentración considerablemente alto, ocasionando efectos adversos. Ante los grandes problemas ambientales que éstos ocasionan en la cadena alimentaria, se han formulado diversos métodos para mitigar los daños, entre los que se encuentran el empleo de métodos enzimáticos asociados a microorganismos o a otros agentes biológicos, y sistemas que permiten el metabolismo de contaminantes de forma efectiva y práctica. Utilizar de manera conjunta estos sistemas, aparece como la opción más acertada para eliminar agentes de polución a un costo energético razonable, lo cual permite emplearlos en la industria. En la presente revisión se identifican las condiciones de proceso propicias para la implementación tecnológica de sistemas membranarios tipo biopelícula que utilizan microorganismos productores de laccasa como agentes de descontaminación.

Palabras clave: laccasa, biofilmina, sistema membranario, compuestos halogenados. 


\section{LITERATURE CITED}

Aksu, Z., and S. Tezer. 2000. Equilibrium and kinetic modeling of biosorption of Remazol Black B by Rhizopus arrhizus in a batch system: effect of temperature. Process Biochem. 36:431-439.

Aksu, Z., N. Kilic, S. Ertugrul, and G. Dönmez. 2007. Inhibitory effects of chromium (VI) and Remazol Black B on chromium(VI) and dyestuff removals by Trametes versicolor. Enzyme Microb. Technol. 40:1167-1174.

Alvarez, M. 2006. Enhancement of sulphide production in anaerobic packed bed bench-scale biofilm reactors by sulphate reducing bacteria. Biotechnol. Lett. 28:175-181.

Banat, I.M., P. Nigam, D. Singh, and R. Marchant. 1996. Microbial decolorization of textile-dye-containing effluents: a review. Bioresour. Technol. 58:217227.

Bhat, T.R., D. Venkataramani, V. Ravi, and C. Murty. 2006. An improved differential evolution method for efficient parameter estimation in biofilter modeling. Biochem. Eng. J. 28:167-176.

Canovas-Diaz, M., and J.A. Howell. 1988. Stratified mixed culture biofilm model for anaerobic digestion. Biotechnol. Bioeng. 32:348-355.

Cerniglia, C.E., and J.B. Sutherland. 2006. Relative roles of bacteria and fungi in polycyclic aromatic hydrocarbon biodegradation and bioremediation of contaminated soils. p. 182-211. In Gadd, G.M. (ed.) Fungi in biogeochemical cycles. Cambridge University Press, Cambridge, UK.

Cho, K.S., H. Ryu, and N. Lee. 2000. Biological deodorization of hydrogen sulphide using porous lava as a carrier of Thiobacillus thiooxidans. J. Biosci. Bioeng. 90:25-31.

Choi, J.H., Y. Kim, and J. Choi. 2007. Reductive dechlorination and biodegradation of 2,4,6-trichlorophenol using sequential permeable reactive barriers: Laboratory Studies. Chemosphere 67:1551-1557.

Dalfard, A., K. Khajeh, M. Soudi, H. Manesh, B. Ranjbar, and R. Sajedi. 2006. Isolation and biochemical characterization of laccase and tyrosinase activities in a novel melanogenic soil bacterium. Enzyme Microb. Technol. 39:1409-1416.

Darling, W.G., and D.C. Gooddy. 2007. Assessing the applicability of global $\mathrm{CFC}$ and $\mathrm{SF}_{6}$ input functions to groundwater dating in the UK. Sci. Total Environ. 387(1-3):353-362.
Derwent, R.G., P. Simmonds, B. Greally, S. O’Doherty, A. McCulloch, A. Manning, et al. 2007. The phasein and phase-out of European emissions of HCFC$141 \mathrm{~b}$ and HCFC-142b under the Montreal Protocol: Evidence from observations at Mace Head, Ireland and Jungfraujoch, Switzerland from 1994 to 2004. Atmos. Environ. 41:757-767.

Fang, S., and Y. Mu. 2007. NOX fluxes from three kinds of agricultural lands in the Yangtze Delta, China. Atmos. Environ. 41:4766-4772.

Freitas dos Santos, L.M., P. Pavasant, L.F. Strachan, E.N. Pistikopoulos, and A.G. Livingston. 1997. Membrane attached biofilms for waste treatment-fundamentals and applications. Pure Appl. Chem. 11:2459-2469.

Gabriel, D., and M.A. Deshusses. 2003. Performance of a full-scale biotrickling filter treating $\mathrm{H} 2 \mathrm{~S}$ at a gas contact time of 1.6 to 2.2 seconds. Environ. Progr. 22:111-118.

Gadd, G. 2007. Geomycology: biogeochemical transformations of rocks, minerals, metals and radionuclides by fungi, bioweathering and bioremediation. Mycol. Res. 111:3-49.

Garner, L.G., and T.A. Barton. 2002. Biofiltration for abatement of VOC and HAP emissions. Met. Finish. 100(11):12-18.

Gnanamani, A.M., M. Jayaprakashvel, and S. Arulmani. 2006. Effect of inducers and culturing processes on laccase synthesis in Phanerochaete chrysosporium NCIM 1197 and the constitutive expression of laccase isozymes. Enzyme Microb. Technol. 38:1017-1021.

Ho, K.L., Y. Cheng, and C. Tseng. 2007. Continuous deodorization and bacterial community analysis of a biofilter treating nitrogen-containing gases from swine waste storage pits. Biores. Technol. 8:2757-2765.

Huang, Q. 2003. Effects of several low-molecular weight organic acids and phosphate on the adsorption of acid phosphatase by soil colloids and minerals. Chemosphere 52:571-579.

Jarosz-Wilkolazka, A., M. Graz, B. Braha, S. Menge, D. Schlosser, and G.J. Krauss. 2006. Species-specific Cd-stress response in the white rot basidiomycetes Abortiporus biennis and Cerrena unicolor. Biometals 19:39-49.

Jin, L., W. Lee, C.H. Lee, I.S. Chang, X. Huang, and T. Swaminathan. 2006. Effect of DO concentration on biofilm structure and membrane filterability in submerged membrane bioreactor. Water Res. 40:2829-2836.

Jin-Ying, X., H. Hong-Ying, Z. Hong-Bo, and Q. Yi. 2005. Effects of adding inert spheres into the filter bed on the performance of biofilters for gaseous toluene removal. Biochem. Eng. J. 23:123-130. 
Jung, H., F. Xu, and K. Li. 2002. Purification and characterization of laccase from wood-degrading fungus Trichophyton rubrum LKY-7. Enzyme Microb. Technol. 30:161-168.

Kapdan, I., F. Kargi, G. McMullan, and R. Marchant. 2000. Comparison of white rot fungi cultures for decolourisation of textile dyestuffs. Bioprocess Eng. 22:347-351.

Khayet, M. 2003. The effects of air gap length on the internal and external morphology of hollow fiber membranes. Chem. Eng. Sci. 58:3091-3104.

Kim, D., and G.A. Sorial. 2007. Role of biological activity and biomass distribution in air biofilter performance. Chemosphere 66:1758-1764.

Kinney, K.A., C.A. Plessis, E.D. Schroeder, D. Chang, and K.M. Scow. 1996. Optimizing microbial activity in a directionally switching biofilter. p. 150-157. Conference on biofiltration, University of Southern California, Davis, California, USA.

Kirby, N. 1999. Bioremediation of textile industry wastewater by white rot fungi. 90 p. Ph.D. Thesis. University of Ulster, Coleraine, UK.

Koe, L.C.C., L. Wu, Y. Loo, and Y. Wu. 2001. Field trial testing of a biotrickling filter for sewage odour control. p. 902-950. A\&WMA's 94th Annual Conference \& Exhibition, Orlando. 24-28 June. The Air \& Waste Management Association, Pittsburgh, Pennsylvania, USA.

Kosaric, N., and R. Blaszczyk. 1991. Aerobic granular sludge and biofilm reactors. Adv. Biochem. Eng. 41:28-31.

Kunla, M., B. Novotný, and K. Svobodová. 2007. The implication of Dichomitus squalens laccase isoenzymes in dye decolorization by immobilized fungal cultures. Biores. Technol. 98:2109-2115.

Lee, T.H., H. Aoki, Y. Sugano, and M. Shoda. 2000. Effect of molasses on the production and activity of dye decolorizing peroxidase from Geotrichum candidum Dec1. J. Biosci. Bioeng. 89:545-549.

Li, X., and X. Wang. 2006. Modeling of membrane fouling in a submerged membrane bioreactor. J. Membrane Sci. 278:151-161.

Luke, A.K., and S.G. Burton. 2001. A novel application for Neurospora crassa: Progress from batch culture to a membrane bioreactor for the bioremediation of phenols. Enzyme Microb. Technol. 29:348-356.

Malato, S. 2003. Applied studies in solar photocatalytic detoxification: an overview. Solar Energy 75:329336.

Mandel, S. 2007 Activity-dependent neuroprotective protein (ADNP) differentially interacts with chromatin to regulate genes essential for embryogenesis. Dev. Biol. 303:814-824.
McCulloch, A., P.M. Midgley, and A.A. Lindley. 2006. Recent changes in the production and global atmospheric emissions of chlorodifluoromethane (HCFC-22). Atmos. Environ. 40:936-942.

Miller, M., and D. Grant. 2005. Modeling transport and degradation of hydrophobic pollutants in biofilter biofilms. Chem. Eng. J. 113:197-204.

Montgomery, R. 2004. Development of biobased products. Biores. Technol. 91:1-29.

Novotny, C., P. Erbanova, T. Cajthaml, N. Rothschild, C. Dosoretz, and V. Sasek. 2000. Irpex lacteus, a white rot fungus applicable to water and soil bioremediation. Appl. Microbiol. Biotechnol. 54:850-853.

Nukunya, T., J.S. Devinny, and T.T. Tsotsis. 2005. Application of a pore network model to a biofilter treating ethanol vapor. Chem. Eng. Sci. 60:665-675.

Osma, J.F., J. Toca Herrera, and S. Rodríguez Couto. 2007. Banana skin: A novel waste for laccase production by Trametes pubescens under solid-state conditions. Application to synthetic dye decolouration. Dyes Pigments 75:32-37.

Pedroza, A. 2007. Sequential treatment via Trametes versicolor and $\mathrm{UV} / \mathrm{TiO} / \mathrm{RuxSey}$ to reduce contaminants in waste water resulting from the bleaching process during paper production. Chemosphere 67:793-801.

Prasad, K.K., S. Venkata Mohan, R. Sreenivas Rao, P. Ranjan Bikas, and P.N. Sarma. 2005. Laccase production by Pleurotus ostreatus 1804: Optimization of submerged culture conditions by Taguchi DOE methodology. Biochem. Eng. J. 24:17-26.

Raghavarao, K.S., T.V. Ranganathan, and N.G. Karanth. 2003. Some engineering aspects of solid-state fermentation. Biochem. Eng. J. 13:127-135.

Rajeswari, K.V., M. Balakrishnan, A. Kansal, K. Lata, and V.N. Kishore. 2000. State of the art of anaerobic digestion technology for industrial waste water treatment. Renew. Sustain. Energy Rev. 4:135-156.

Ramos, J.L. 2005. Bioremediation of polynitrated aromatic compounds: plants and microbes put up a fight. Environ. Biotechnol. 16:275-281.

Robles, A., L. Rosario, M. Martínez-Cañamero, N. Omar, R. Pérez, and A. Gálvez. 2002. Characterization of laccase activity produced by the hyphomycete Chalara (syn. Thielaviopsis) paradoxa CH32. Enzyme Microb. Technol. 31:516-522.

Rosales, E., S. Rodriguez Couto, and M. Sanromán. 2007. Increased laccase production by Trametes hirsuta grown on ground orange peelings. Enzyme Microb. Technol. 40:1286-1290.

Sahinkaya, E., and F. Dilek. 2007. Effect of feeding time on the performance of a sequencing batch reactor treating a mixture of 4-CP and 2,4-DCP. J. Environ. Manage. 83:427-436. 
Savant, D.V., R. Rahman, and D.R. Ranade. 2006. Anaerobic degradation of adsorbable organic halides (AOX) from pulp and paper industry wastewater. Biores. Technol. 97:1092-1104.

Smet, E., G. Chasaya, H. Van Langenhove, and W. Verstraete. 1996. The effect of inoculation and the type of carrier material used on the biofiltration of methyl sulphides. Appl. Microbiol. Biotechnol. 45:293-298.

Soccol, C.R., A.L. Woiciechowski, S. Vandenberghe, M. Soares, G.K. Neto, and V. T. Soccol. 2003. Biofiltration: an emerging technology. Indian J. Biotechnol. 2:396-410.

Solomon, U.M., and T.E. Sundaram. 1996. Multicopper oxidases and oxygenases. Chem. Rev. 96:25632605.

Sorial, G.A., F.L. Smith, M.T. Suidan, A. Pandit, P. Biswas, and R.C. Brenner. 1998. Evaluation of trickle-bed air biofilter performance for styrene removal. Water Res. 32:1593-1603.

Sugimori, D., R. Banzawa, M. Kurozumi, and I. Okura. 1999. Removal of disperse dyes by the fungus Cunninghamella polymorpha. J. Biosci. Bioeng. 87:252-254.

Sun, D., C. Hay, and S. Khor. 2006. Effects of hydraulic retention time on behavior of start-up submerged membrane bioreactor with prolonged sludge retention time. Desalination 195:209-225.

Tartakovsky, B. 2005. Degradation of trichloroethylene in a coupled anaerobic-aerobic bioreactor: Modeling and experiment. Biochem. Eng. J. 26:72-81.
Tran, T., S. Gray, R. Naughton, and B. Bolto. 2006. Polysilicato-iron for improved NOM removal and membrane performance. J. Membrane Sci. 280:560571.

Ünyayar, A, M. Mazmanci, H. Ataçag, E. Erkurt, and G. Coral. 2005. A Drimaren Blue X3LR dye decolorizing enzyme from Funalia trogii: one step isolation and identification. Enzyme Microb. Technol. 36:10-16.

Verdin, A. 2004. Degradation of benzo[a]pyrene by mitosporic fungi and extracellular oxidative enzymes. Int. Biodeter. Biodegr. 53:65-70.

Vladisavljevic, G.T., M. Shimizu, and T. Nakashima. 2006. Production of multiple emulsions for drug delivery systems by repeated SPG membrane homogenization: Influence of mean pore size, interfacial tension and continuous phase viscosity. J. Membrane Sci. 284:373-383

Wang, L., and X. Wang. 2006. Study of membrane morphology by microscopic image analysis and membrane structure parameter model. J. Membrane Sci. 283:109-115.

Whiteley, C., and D. Lee. 2006. Enzyme technology and biological remediation. Enzyme Microb. Technol. 38:291-316.

Xu, F. 1996. Oxidation of phenols, anilines, and benzenethiols by fungal laccases: correlation between activity and redox potentials as well as halide inhibition. Biochemistry 35:7608-7614.

Yang, Y.H., and E.R. Allen. 1994. Biofiltration control of hydrogen sulphide 1. Design and operational parameters. J. Air Waste Manage. Assoc. 44:863-868. 


\section{ERRATUM}

In journal Vol. $68 \mathrm{~N}^{\circ} 3$ :

On p. 221, please add in the footnote the authors' affiliation: Dr. Reinaldo Campos-Vargas and Dr. Bruno G. Defilippi: "Plant Cell Biotechnology Millenium Nucleus".

On p. 230, the last line before RESULTS says "Figures 1 to 4"; it should read "Figures 1 to 3".

On p. 284, INTRODUCTION, line 4 says "Prunas avium"; it should read "Prunus avium".

On p. 295, Palabras clave, must say "residuos de té”. 